\title{
Genetic differentiation of Phoma sp. isolates using retrotransposon-based iPBS assays
}

\section{Vilnis Šḳipars ${ }^{1 *}$, Maryna Siaredzich², Viktorija Belevich ${ }^{1}$, Natālija Bruṇeviča ${ }^{1}$, Lauma Brūna ${ }^{1}$, Dainis E. Rungóis ${ }^{1}$}

\author{
${ }^{1}$ Latvian State Forest Research Institute „Silava”, Rīgas 111, Salaspils LV-2169, Latvia \\ ${ }^{2}$ Forest Protection and Wood Science Department, Belarusian State Technological University, Sverdlova 13A, Minsk 220006, Belarus \\ *Corresponding author, E-mail: vilnis.skipars@silava.lv
}

\begin{abstract}
Phoma blight is a disease affecting Norway spruce, Scots pine and other conifer seedlings in many forest tree nurseries throughout the world. Members of the Phoma genus, the causatives of this disease, are difficult to distinguish morphologically and genetically. In this study the use of a retrotransposon-based polymerase chain reaction approach using iPBS amplification for intra-species genetic discrimination between Phoma samples is described. Eight retrotransposon-based iPBS primers were used to genotype DNA from pure cultures of several Phoma species. The utilised markers were able to discriminate between Phoma species, but not all of them were able to differentiate all Phoma sp. isolates investigated. Belarusian samples were found to be distinct from the Latvian Phoma isolates. The Belorussian isolates were very similar to each other. A combination of three iPBS markers (2001, 2076 and 2242) enabled partial differentiation of the investigated Belarusian Phoma isolates.
\end{abstract}

Key words: genetic discrimination, inter primer binding site (iPBS) markers, Phoma sp. Abbreviations: iPBS, inter primer binding site.

\section{Introduction}

Phoma blight is an infectious disease associated with several species of Phoma that affect several species of firs and pines and cause significant damage in tree nurseries in the USA (Srago et al. 1989). Phoma eupyrena is also associated with upper stem canker in Douglas fir (Hamm et al. 1989). Phoma blight causes considerable economic damage in Belarusian tree nurseries, affecting 5 to $15 \%$ of Pinus sylvestris and Picea abies seedlings (Siaredzich 2017). Phoma spp. was found to be the most common pathogen of P. sylvestris, Larix sibirica, P. abies, Pinus sibirica and Abies sibirica in Russian forest nurseries of the Novosibirsk region (Larionova et al. 2017). In contrast, in Latvian coniferous forest tree nurseries Phoma sp. is not considered a threat or is successfully managed. This is inferred from the absence of Phoma sp. related disease outbreaks in conifer tree nurseries in Latvia (Brūna, unpublished results). A study about root-associated fungi in healthy-looking P. sylvestris and $P$. abies seedlings in Swedish forest nurseries showed members of Phoma genus as commonly present on roots of healthy-looking samples not excluding a possibility of latent infection that could activate after outplanting (Stenström et al. 2014). However, representatives of Phoma herbarum, Phoma glomerata and Phoma adonidicola as well as an unidentified Phoma sp. were isolated by members of the Latvian State Forest Research Institute
"Silava" phytopathology and mycology department from Betula pendula samples collected in local tree nurseries (Brūna, unpublished results), and members of the Phoma genus have also been isolated from grey alder and Norway spruce samples taken from Latvian forest ecosystems, (Arhipova et al. 2011a; Arhipova et al. 2011b). Interestingly, $P$. herbarum has been described as potentially beneficial for plant growth (Muhammad et al. 2009), including in Scots pine (Sanz-Ros et al. 2015), and has also been used as a biological control agent against Taraxacum officinale (Neumann Brebaum 1998). P. glomerata has been described as having mycoparasitic properties (Sullivan, White 2000), as an endophyte (Deng et al. 2011), as a pathogen causing boxwood tip blight (Horst 2001), cankers of peach trees (Thomidis et al. 2011) and, according to the American Phytopathological Society, phoma canker in elm (https:// www.apsnet.org/publications/commonnames/Pages/Elm. aspx). Phoma macrostoma var. incolorata has been reported to inhibit the growth of the ash pathogen Hymenoscyphus fraxineus (Haňácková et al. 2017). These reports show that Phoma species can play vastly different roles in different conditions and host species.

Phoma species are difficult to identify due to the withinspecies variation of morphological features when cultivated in vitro (Aveskamp et al. 2008). The available information about the genetics of Phoma is increasing. The genome of a Phoma member called Phoma sp 1 has been sequenced by 
the Forest Institute of the National Academy of Sciences of Belarus (Baranov et al. 2015). The genotype has not been definitely assigned to a species, and whole genome shotgun sequences of the P. herbarum strain JCM 15942 have been made available by Manabe et al. from RIKEN Center for Life Science Technologies, Japan (NCBI SRA database accession numbers DRX033246 \& DRX029297). Another sequencing project involving Phoma tracheiphila, a citrus pathogen, is under way in U.S. Department of Energy Joint Genome Institute (NCBI SRA database accession numbers SRX1728765, SRX1728766 and SRX1728771). Presently the identification of Phoma species as well as discrimination between isolates and species is still difficult and time consuming. This is because the DNA regions used for species differentiation show low sequence polymorphism, and therefore several DNA regions have to be analysed. One of the most detailed reports of the genetic discrimination of taxa of the Phoma genus used sequencing of three different loci: the ITS1-5.8S-ITS2 region (ITS) of the nuclear ribosomal DNA operon, part of the actin gene, and part of the $\beta$-tubulin gene (Aveskamp et al. 2009). Additional use of the RNA polymerase II second largest subunit ( $r p b 2$ ) was employed by Chen et al. (2015b) to increase resolution. Translation elongation factor 1 subunit (tef1) has also been used for phylogenetic studies of Phoma (Irinyi et al. 2007). A short yet comprehensive review regarding identity determination of Phoma by multiple approaches, including additional DNA markers, is provided by Rai et al. (2014). Use of large numbers of samples both for pathogen screening in nurseries and for population genetics studies is time-consuming and expensive.

The iPBS method (Kalendar et al. 2010) might serve as a tool for differentiation between Phoma sp. isolates. This method relies on the non-uniform distribution of retrotransposon elements in the genomes of different isolates and species and allows for greater discriminatory power. This procedure is cost-effective, less timeconsuming and allows differentiation between isolates of the same or different species. In addition to providing information on genetic diversity, retrotransposons can be used for identification of a certain pathogen if sufficient genetic information is available (Fernandez et al. 1998), differentiation between isolates (Pasquali et al. 2007) and have also been shown to influence pathogenicity of plant pathogens (Mouyna et al. 1996) and plant resistance against them (McDowell, Meyers 2013). The aim of the study was to utilise iPBS markers to investigate the genetic diversity of Phoma sp. isolates collected in several Belarusian forest nurseries, and to compare the Belarusian samples with Phoma samples isolated from Latvian forests. Sequencing of the intergenic transcribed spacer region of ribosomal RNA genes was also performed for the Belarusian samples to obtain additional data for phylogenetic comparison to publicly available Phoma sp. sequences.

\section{Materials and methods}

\section{Material}

DNA from twelve pure cultures of Phoma sp., each obtained from a different forest tree nursery in Belarus and five Latvian Phoma isolates, obtained from trees of several species growing in Latvian forests was extracted for genetic analyses of these isolates. Sequences of 12 Latvian Phoma DNA samples (Z9B - Z300) previously obtained by $\mathrm{N}$. Bruneviča (unpublished data) were used in the analysis (Table 1). DNA isolation was carried out using the Genomic DNA purification kit (ThermoFisher Scientific) according to the manufacturer's protocol. According to morphological characteristics, the Belarusian samples were inferred to be P. glomerata or P. macrostoma, but the species could not be determined conclusively.

\section{Sequencing analysis}

DNA sequences of intergenic transcribed spacer region of ribosomal RNA genes were obtained from PCR amplicons

Table 3. Phoma isolates analysed in the present study

\begin{tabular}{lll} 
Isolate & Taxon & Origin \\
N04 & Phoma sp. & Belarus \\
N04.1 & Phoma sp. & Belarus \\
N06 & Phoma sp. & Belarus \\
N07 & Phoma sp. & Belarus \\
N10 & Phoma sp. & Belarus \\
N12 & Phoma sp. & Belarus \\
N13 & Phoma sp. & Belarus \\
\hline N14 & Phoma sp. & Belarus \\
N16 & Phoma sp. & Belarus \\
N17 & Phoma sp. & Belarus \\
N19 & Phoma sp. & Belarus \\
\hline N20 & Phoma sp. & Belarus \\
LV07 & Phoma glomerata & Latvia \\
LV07v & Phoma sp. & Latvia \\
LV08k & Phoma herbarum & Latvia \\
LV09v & Phoma herbarum & Latvia \\
LV249 & Phoma herbarum & Latvia \\
Z9B & Phoma herbarum & Latvia \\
Z18 & Phoma adonidicola & Latvia \\
Z47 & Phoma herbarum & Latvia \\
Z78 & Phoma sp. & Latvia \\
Z94 & Phoma sp. & Latvia \\
Z130 & Phoma sp. & Latvia \\
Z158 & Phoma herbarum & Latvia \\
Z163 & Phoma herbarum & Latvia \\
Z178 & Phoma sp. & Latvia \\
Z215 & Phoma glomerata & Latvia \\
Z268 & Phoma herbarum & Latvia \\
Z300 & Phoma glomerata & Latvia \\
\hline
\end{tabular}


obtained with primers ITS1-F and ITS4-B (Gardes, Bruns 1993) from the Belarusian samples. Sanger sequencing was performed using the BigDye $e^{\oplus}$ Terminator v3.1 Cycle Sequencing Kit (ThermoFisher Scientific) according to the manufacturer's protocol.

\section{Retrotransposon-based $P C R$ assays (iPBS)}

Primers 2001, 2009, 2010, 2076, 2081, 2083, 2097, 2220, 2239, 2242, 2380 and 2384 (Kalendar et al. 2010) were used in PCR reactions of the following composition (total reaction volume $20 \mu \mathrm{L}$ ): $5 \mathrm{x}$ HOT FIREPol $^{\circ}$ Blend Master Mix Ready to Load with $10 \mathrm{mM} \mathrm{MgCl}_{2}$ (Solis BioDyne) $4 \mu \mathrm{L}$, final primer concentration $2 \mu \mathrm{M}, 10 \mathrm{ng}$ of DNA. Thermal cycling was performed as follows: $95{ }^{\circ} \mathrm{C} 15 \mathrm{~min}$ initial denaturation followed by 38 cycles of denaturation at $95^{\circ} \mathrm{C}$ for $30 \mathrm{~s}$, annealing at $50^{\circ} \mathrm{C}$ for $40 \mathrm{~s}$ and elongation at $72{ }^{\circ} \mathrm{C}$ for $3 \mathrm{~min}$. The cycling program ended with final extension at $72{ }^{\circ} \mathrm{C}$ for $10 \mathrm{~min}$. PCR products were analysed on $2 \%$ agarose gel, $1 \times$ TAE buffer, and visualised by ethidium bromide staining. iPBS analysis was performed for the seven Belarusian samples.

\section{Data analysis}

The iPBS amplification results were encoded as binary data. Genetic distances were calculated using GenAlex 6.5 (Peakall, Smouse 2012) and phylogenetic trees created using the MEGA software (Kumar et al.2018) by use of the UPGMA (Unweighted Pair Group Method with Arithmetic Mean) algorithm (Nei, Kumar 2000). Dendrograms were also created from trimmed sequences of intergenic transcribed spacer (ITS) region of ribosomal RNA genes using the MEGA software. The graphical comparison of sequences of ITS regions of Belarusian isolates were prepared with the AlignX module of the Vector NTI software (Thermo Fisher Scientific).

\section{Results}

The ITS sequences obtained from pure cultures of Belarusian Phoma samples were highly similar and matched closely (99\% nucleotide sequence similarity) to sequences from unidentified Phoma species, P. glomerata, Phoma pomorum, P. macrostoma and other species in the NCBI database. The closest similarity was determined to be to Phoma sp. isolate $701 \mathrm{AI}-2013$, NCBI GenBank sequence accession number KC662226, from Minnesota, USA (Impullitti, Malvick 2013). There was no exact match to a database accession sequence. The only difference between the obtained sequences was that samples 19 and 20 harboured a SNP mutation not present in the other samples (nt $460 \mathrm{~T}$ $\rightarrow$ A) (Appendix 1). The observed genetic polymorphism was low and exact species identification or discrimination between isolates was not possible. Thus sequencing analysis suggested that the sequences belonged to a single taxon.

The utilised iPBS method identified a higher level
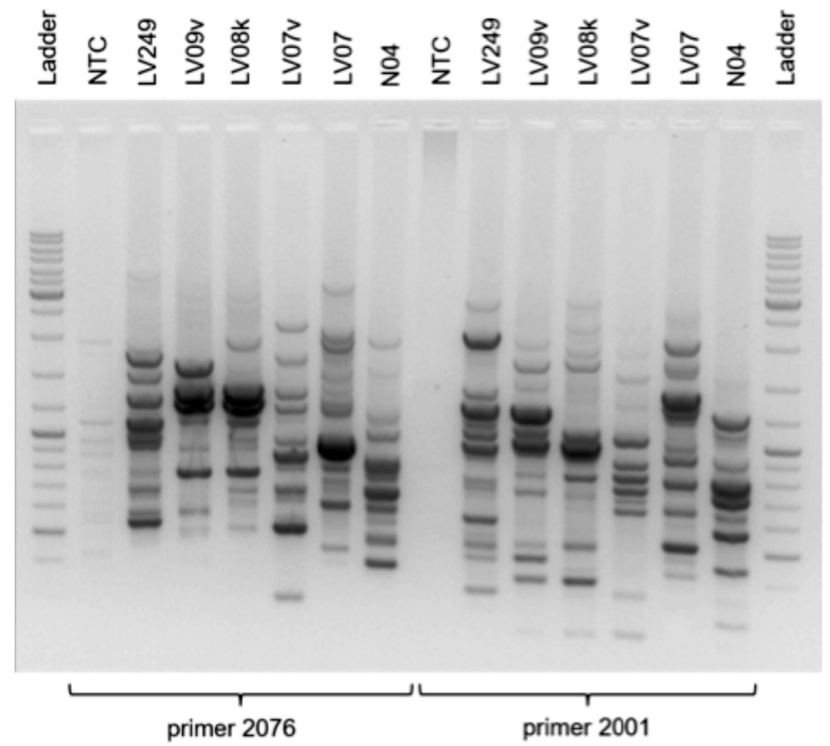

Fig. 1. Comparison of Belarusian Phoma sp. isolate (N04) to Latvian $P$. glomerata and $P$. herbarum isolates, electrophoresis results of iPBS assays with primers 2001 and 2076.

of polymorphism. Eight informative iPBS primers were utilised for genotyping of the Latvian and Belarussian Phoma isolates (2001, 2009, 2010, 2076, 2081, 2083, 2097 and 2220).

The Belarusian Phoma isolates showed obvious differences from Latvian $P$. glomerata and $P$. herbarum isolates and probably represent a different Phoma species (Fig. 1). The Belarusian Phoma isolates were very similar to each other, with only a low level of genetic diversity detected. However, three different genotypes with primer 2079 and three with primer 2001 (ignoring fainter bands) were identified within the Belarusian Phoma isolates (Fig. 2 ). Two genotypes within the Belarusian samples were identified with primer 2242 (faint bands in the bottom

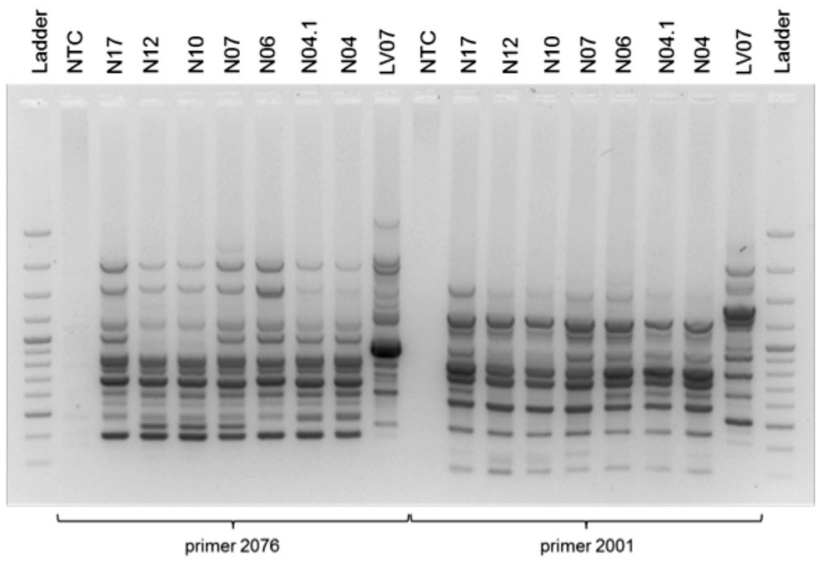

Fig. 2. Comparison of Belarusian Phoma sp. isolates among themselves and to a Latvian P. glomerata sample (LV07), electrophoresis results of iPBS assays with primers 2001 and 2076. 


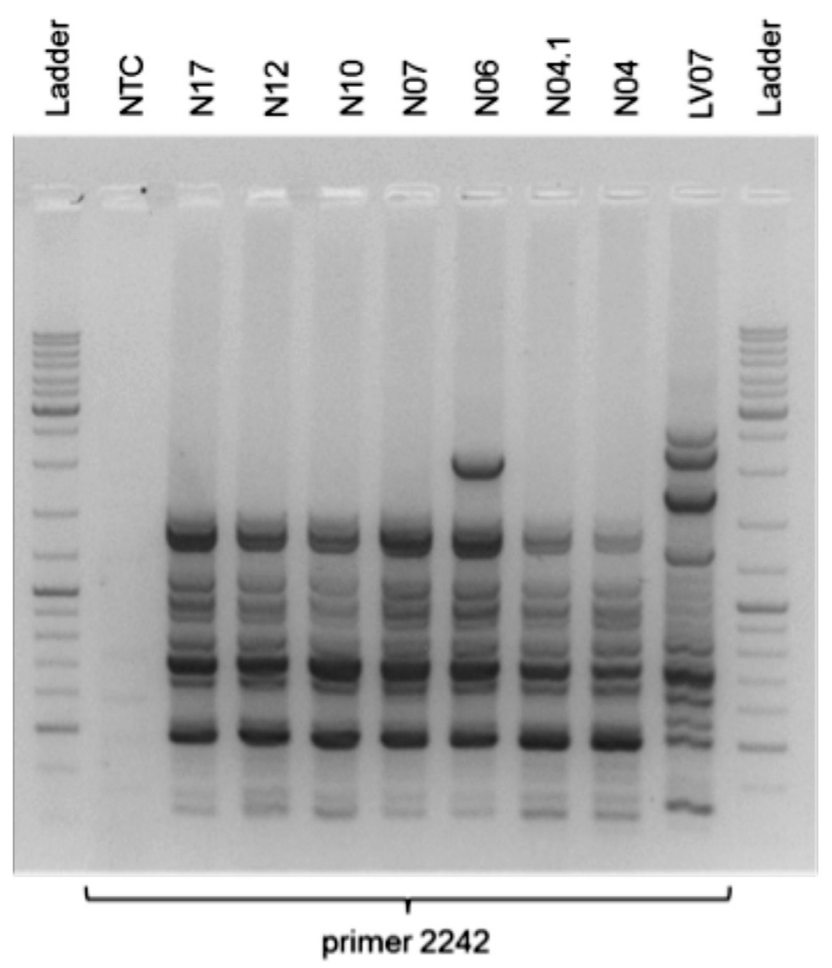

Fig. 3. Comparison of Belarusian Phoma sp. isolates among themselves and to a Latvian $P$. glomerata sample (LV07), electrophoresis results of iPBS assays with primer 2242 .

of the gel were not considered) (Fig. 3). Pairwise genetic distances between the Latvian and Belarusian samples were calculated based on the presence or absence of 50 amplified fragments from two iPBS assays (primers 2001 and 2076), and a UPGMA phylogenetic tree was constructed (Fig. 4). The use of an additional iPBS assay (2242) in conjunction with the previous assays (2001 and 2076), allowed one of the previously undifferentiated Belarusian samples to be uniquely genotyped (isolate N6; Fig. 5). However, it was not possible to differentiate three isolates (N4, N4.1, N17).

Comparison of the ITS sequences of the Belarusian samples, the Belarusian sample with full genome information (Phoma sp1), Latvian samples (representing $P$. glomerata, Phoma adonidicola and P. herbarum), sequences published by Aveskamp et al. (2009) (P. glomerata) and other sequences from the NCBI database (P. macrostoma), revealed that the Belarusian samples most likely represent P. macrostoma or P. glomerata (Fig. 6, Appendix 2), which is in agreement with the morphological characteristics of these samples.

\section{Discussion}

Low genetic polymorphism in the ITS sequence analysis was expected, as previous studies on the Phoma genus indicated the necessity of additional DNA analyses, besides the ITS region analysis for better discrimination between

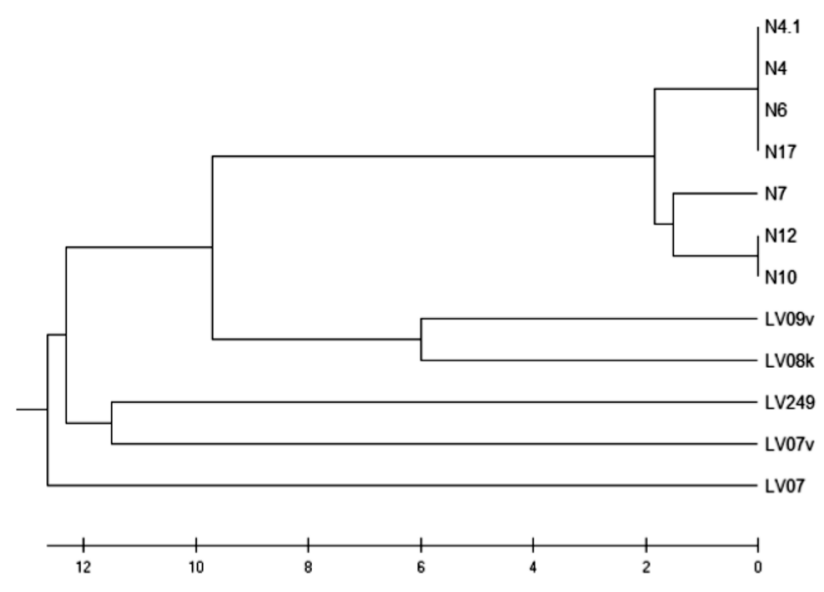

Fig.4. UPGMA dendrogram based on pairwise genetic distances between Latvian and Belarusian Phoma samples based on iPBS assays with primers 2001 and 2076.

species of the Phoma genus (Aveskamp et al.2009; Chen et al.2015b). Analysis of multiple conserved DNA regions can be time consuming and expensive. In contrast, genotyping using iPBS markers does not provide direct information about the sequences of produced amplicons without further investigation, but employs a simple PCR reaction followed by electrophoresis, which can be achieved quickly and at reduced cost. The nature of this method, employing the non-uniform distribution of retrotransposon elements in the genomes of different isolates and species, allows for greater discriminatory power. The number and affiliation of long terminal repeat transposable elements varies between fungal species (Muszewska et al.2011) and isolates of the same species (Özer et al. 2016; Özer et al. 2017). The disadvantages of this method are similar to those of randomly amplified polymorphic DNA (RAPD) analysis, including the necessity for strict standardisation (Kumari, Thakur 2014) and problems associated with non-template specific PCR amplification products (Lamboy 1994), which were also observed for some of the markers utilised in this study. However, while issues of reproducibility and fragment size homoplasy need to be considered, genotyping with iPBS markers is more sensitive and accurate compared to RAPD markers (Poczai et al. 2013). The utilised iPBS primers were

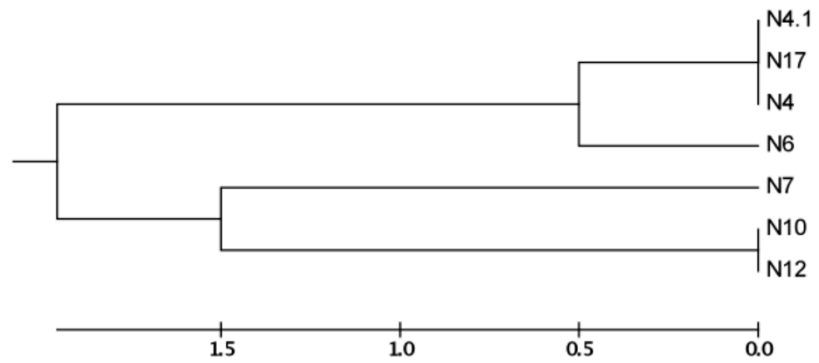

Fig.5. UPGMA dendrogram based on pairwise genetic distances between Belarusian Phoma samples based on iPBS assays with primers 2001, 2076 and 2242. 


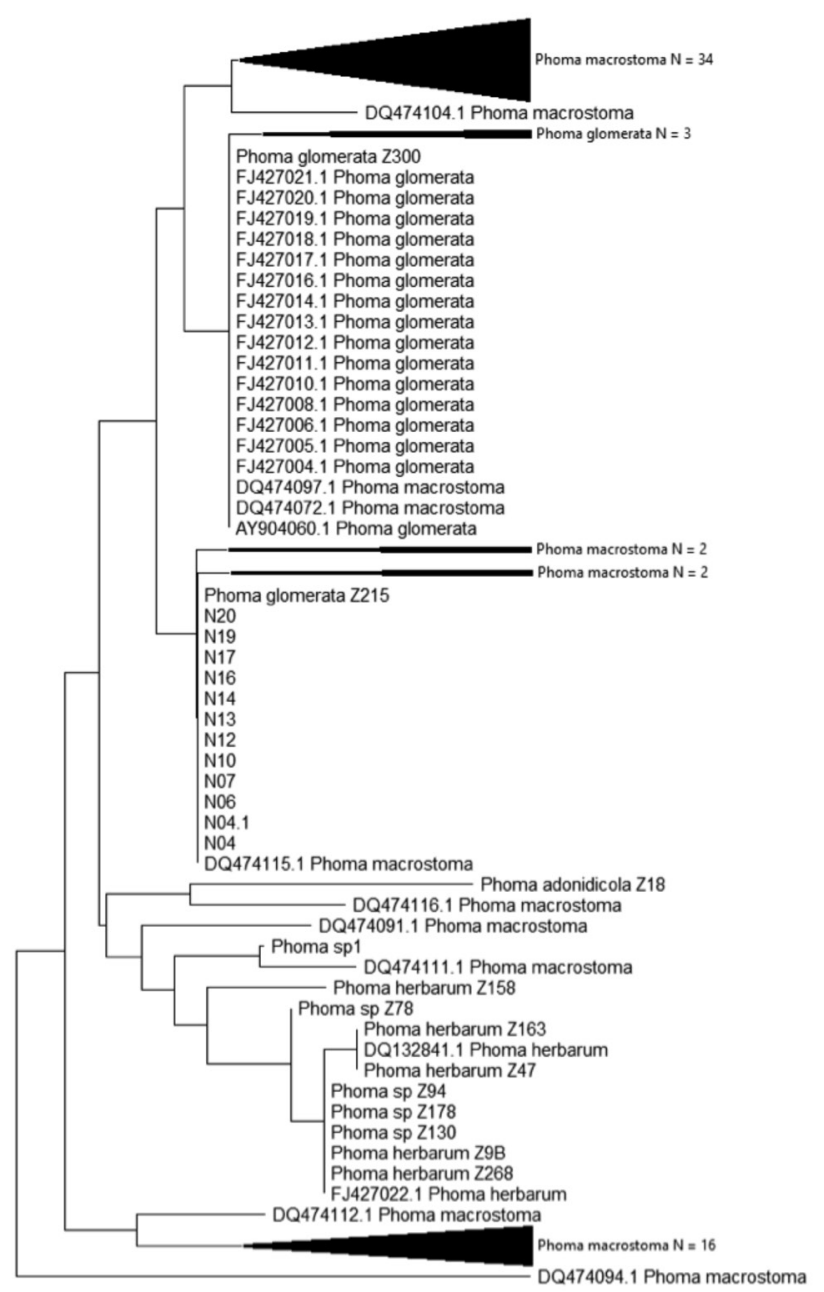

Fig.6. Phylogenetic relationship of analysed Phoma isolates and NCBI database accessions based on ITS sequencing.

able to partly differentiate between the analysed Phoma species (sample LV07 was morphologically determined to represent $P$. glomerata and samples LV08k, LV09v and LV249 represented $P$. herbarum). However, some of the Belarussian isolates were not able to be distinguished. The use of iPBS has been previously reported to be more informative than ITS sequence comparison for other fungal pathogens (Pourmahdi, Taheri 2015).

The Belarusian isolates had a high degree of similarity between each other, and in some cases, isolates were not distinguished from each other with the utilised marker set. Each isolate was obtained from a different forest nursery. Therefore there are two possible explanations for the apparent genetic uniformity of these isolates. The first possibility is that the markers utilised were not sufficiently informative to distinguish these isolates, and therefore, the use of additional markers may identify additional genetic polymorphism. However, the Latvian Phoma isolates, which were obtained from natural forest environments were readily distinguished with the utilised markers, indicating that these markers are sufficiently informative. The second possibility is that there was some transfer of these Phoma isolates between forest nurseries. However, as far as could be determined, the potting soil utilised in all the nurseries was not obtained from one source, and no other possible transfer vectors were identified. One common factor between nurseries was the origin of the seeds, which were obtained from common seed orchards. Further investigation of the genetic diversity of the Belarusian isolates and possible transfer routes is required to resolve this question.

Retrotransposon-based PCR assays can be successfully used for differentiation between different Phoma isolates that are morphologically and genetically (based ITS sequence comparison) identical. Higher genetic diversity between Phoma isolates from Belarus were detected by iPBS (four genotypes) than by sequencing analysis of intergenic transcribed spacer region of ribosomal RNA genes (two genotypes). The sequence based phylogenetic comparison identified clusters matching different taxonomic groups (Fig. 6 and Appendix 2) and the Belarusian isolates were grouped together indicating their distinctiveness from other isolates (and correct morphological characterisation). iPBS assays identified large genetic differences compared to the Latvian sample LV07, which was morphologically characterised as $P$. glomerata. This suggests that the Belarusian samples that were morphologically determined to be either P. glomerata or P. macrostoma are in fact P. macrostoma. Unfortunately, a Latvian P. macrostoma isolate was not available in order to compare it to the Belarusian isolates. The use of iPBS markers represents an efficient method to investigate the intra-specific diversity of fungal isolates, and can be used to characterise disease outbreaks in forest nurseries as well as the genetic diversity of natural fungal populations.

\section{Acknowledgements}

M. Siaredzich would like to thank her scientific supervisor Vasily A. Yarmalovich for his suggestions, help and support.

\section{References}

Arhipova N., Gaitnieks T., Donis J., Stenlid J., Vasaitis R. 2011a. Decay, yield loss and associated fungi in stands of grey alder (Alnus incana) in Latvia. Forestry 84: 337-348.

Arhipova N., Gaitnieks T., Donis J., Stenlid J., Vasaitis R. 2011 b. Butt rot incidence, causal fungi, and related yield loss in Picea abies stands of Latvia. Can. J. Forest Res. 41: 2337-2345.

Aveskamp M.M., De Gruyter J., Crous P.W. 2008. Biology and recent developments in the systematics of Phoma, a complex genus of major quarantine significance. Fungal Divers. 31: $1-18$.

Aveskamp M.M., Verkley G.J.M., De Gruyter J., Murace M.A., Perelló A., Woudenberg J.H.C., Groenewald J.Z., Crous P.W. 2009. DNA phylogeny reveals polyphyly of Phoma section Peyronellaea and multiple taxonomic novelties. Mycologia 101: 363-382. 
Baranov O.Yu., Panteleev S.V., Rubel I.E., Yarmolovich V.A., Seredich M.O.2015. Identification and annotation of repeating sequences in the genome of Phoma sp 1. Collection of Scientific Papers, Institute of Forest of the National Academy of Sciences of Belarus, 183-185. https://www.dropbox.com/s/ tghdzmurifvj038/75.pdf?dl=0

Chen Q., Jiang J.R., Zhang G.Z., Cai L., Crous P.W.2015a. Resolving the Phoma enigma. Stud. Mycol. 82: 137-217.

Chen Q., Zhang K., Zhang G., Lei C. 2015b. A polyphasic approach to characterise two novel species of Phoma (Didymellaceae) from China. Phytotaxa 197: 267-281.

Deng J.X., Paul N.C., Li M.J., Seo E.Y., Sung G.H., Yu S.H. 2011. Molecular characterization and morphology of two endophytic Peyronellaea species from Pinus koraiensis in Korea. Mycobiology 39: 266-271.

Fernandez D., Ouinten M., Tantaoui A., Geiger J.P., Daboussi M.J., Langin T. 1998. Fot1 insertions in the Fusarium oxysporum f. sp. albedinis genome provide diagnostic PCR targets for detection of the date palm pathogen. Appl. Environ. Microbiol. 64: 633-636.

Gardes M., Bruns T.D. 1993. ITS primers with enhanced specificity for basidiomycetes - application to the identification of mycorrhizae and rusts. Mol. Ecol. 2: 113-118.

Hamm P.B., Campbell S.J., Hansen E.M. 1998. Phoma blight. In: Cordell C.E., Anderson R.L., Hoffard W.H., Landis T.D., Smith Jr. R.S., Toko H.V. (eds) Forest Nursery Pests. U.S. Department of Agriculture, Forest Service, Agriculture Handbook No. 680, p. 128.

Haňáčková Z., Havrdová L., Černý K., Zahradník D., Koukol A. 2017. Fungal endophytes in ash shoots - diversity and inhibition of Hymenoscyphus fraxineus. Baltic For. 23: 89-106.

Horst R.K. 2001. Westcott's Plant Disease Handbook. ${ }^{\text {th }}$ Ed. Vol. I. Springer Science + Business Media, New York, 156 pp.

Impullitti A.E., Malvick D.K. 2013. Fungal endophyte diversity in soybean. J. Appl. Microbiol. 114: 1500-1506.

Irinyi L., Kövics G.J., Erzsébet S. 2007. Classification of Phoma species using new phylogenetic marker. Analele Universității din Oradea, Fascicula: Protecția Mediului 12: 63-69.

Kalendar R., Antonius K., Smykal P., Schulman A.H. 2010. iPBS: a universal method for DNA fingerprinting and retrotransposon isolation. Theor. Appl. Genet. 121: 1419-1430.

Kumar S., Stecher G., Li M., Knyaz C., Tamura K. 2018. MEGA $\mathrm{X}$ : Molecular evolutionary genetics analysis across computing platforms. Mol. Biol. Evol. 35: 1547-1549.

Kumari N., Thakur S.K. 2014. Randomly amplified polymorphic DNA - a brief review. Am. J. Anim. Vet. Sci. 9: 6-13.

Lamboy W.F. 1994. Computing Genetic Similarity Coefficients from RAPD Data: The Effects of PCR Artifacts. PCR Meth. Appl. 4: 31-37.

Larionova T.I., Shuvaev D.N., Kalchenko L.I. 2017. DNAidentification of phytopathogens in forest nursery of Novosibirsk region. Proceedings of the $5^{\text {th }}$ international conference "Conservation of Forest Genetic Resources", pp. 108-109.

McDowell J.M., Meyers B.C. 2013. A transposable element is domesticated for service in the plant immune system. Proc. Natl. Acad. Sci. USA 110: 14821-14822.

Mouyna I., Renard J.L., Brygoo Y. 1996. DNA polymorphism among Fusarium oxysporum f. sp. elaeidis populations from oil palm, using a repeated and dispersed sequence "Palm".
Curr. Genet. 30: 174-180.

Muhammad H., Khan S.A., Khan A.L., Rehman G., Sohn E.-Y., Shah A.A., Kim S.-K., Joo G.-J., Lee I.-J. 2009. Phoma herbarum as a new gibberellin-producing and plant growth-promoting fungus. J. Microbiol. Biotechnol. 19: 1244-1249.

Muszewska A., Hoffmann-Sommer M., Grynberg M. 2011. LTR retrotransposons in fungi. PLOS One 6: e29425.

Nei M., Kumar S. 2000. Molecular Evolution and Phylogenetics. Oxford University Press, New York.

Neumann Brebaum S. 1998. Development of an inundative biological weed control strategy for Taraxacum officinale Weber in turf. Doctoral thesis. University of Guelph, Canada.

Özer G., Bayraktar H., Baloch F.S. 2016. iPBS retrotransposons 'A Universal Retrotransposons' now in molecular phylogeny of fungal pathogens. Biochem. Syst. Ecol. 68: 142-147.

Özer G., Sameeullah M., Bayraktar H., Göre M.E. 2017. Genetic diversity among phytopathogenic Sclerotiniaceae, based on retrotransposon molecular markers. Phytopathol. Mediterr. 56: $251-258$.

Pasquali M., Dematheis F., Gullino M.L., Garibaldi A. 2007. Identification of race 1 of Fusarium oxysporum f. sp. lactucae on lettuce by inter-retrotransposon sequence-characterized amplified region technique. Phytopathology 97: 987-996.

Peakall R., Smouse P.E. 2012. GenAlEx 6.5: genetic analysis in Excel. Population genetic software for teaching and researchan update. Bioinformatics 28: 2537-2539.

Poczai P., Varga I., Laos M., Cseh A., Bell N., Valkonen J.P., Hyvönen J. 2013. Advances in plant gene-targeted and functional markers: a review. Plant Methods 9: 6.

Pourmahdi A., Taheri P. 2015. Genetic diversity of Thanatephorus cucumeris infecting tomato in Iran. J. Phytopathol. 163: 19-32.

Rai M.K., Tiwari V.V., Irinyi L., Kövics G.J. 2014. Advances in taxonomy of genus Phoma: polyphyletic nature and role of phenotypic traits and molecular systematics. Indian J. Microbiol. 54: 123-128.

Sanz - Ros A.V., Müller M.M., San Martín R., Diez J.J. 2015. Fungal endophytic communities on twigs of fast and slow growing Scots pine (Pinus sylvestris L.) in northern Spain. Fungal Biol. 119: 870-883.

Siaredzich M. 2017. Justification of actions for protection of planting material of Scots pine and Norway spruce against Phoma blight in forest nurseries in Belarus. Dissertation, Belarusian State Technological University, Minsk, Belarus. /in Russian/

Srago M.D., James R.L., Kliejunas J.T. 1998. Phoma blight. In: Cordell C.E., Anderson R.L., Hoffard W.H., Landis T.D., Smith Jr. R.S., Toko H.V. (eds) Forest Nursery Pests. U.S. Department of Agriculture, Forest Service, Agriculture Handbook No. 680, pp. 54-55.

Stenström E., Ndobe E.N., Jonsson M., Stenlid J., Menkis A. 2014. Root-associated fungi of healthy-looking Pinus sylvestris and Picea abies seedlings in Swedish forest nurseries. Scand. J. Forest Res. 29: 12-21.

Sullivan R.F., White J.F.Jr. 2000. Phoma glomerata as a mycoparasite of powdery mildew. Appl. Environ. Microiol. 66: 425-427.

Thomidis T., Michailides T. J., Exadaktylou E. 2011. Phoma glomerata (Corda) Wollenw. \& Hochapfel a new threat causing cankers on shoots of peach trees in Greece. Eur. J. Plant Pathol. 131: 171 . 


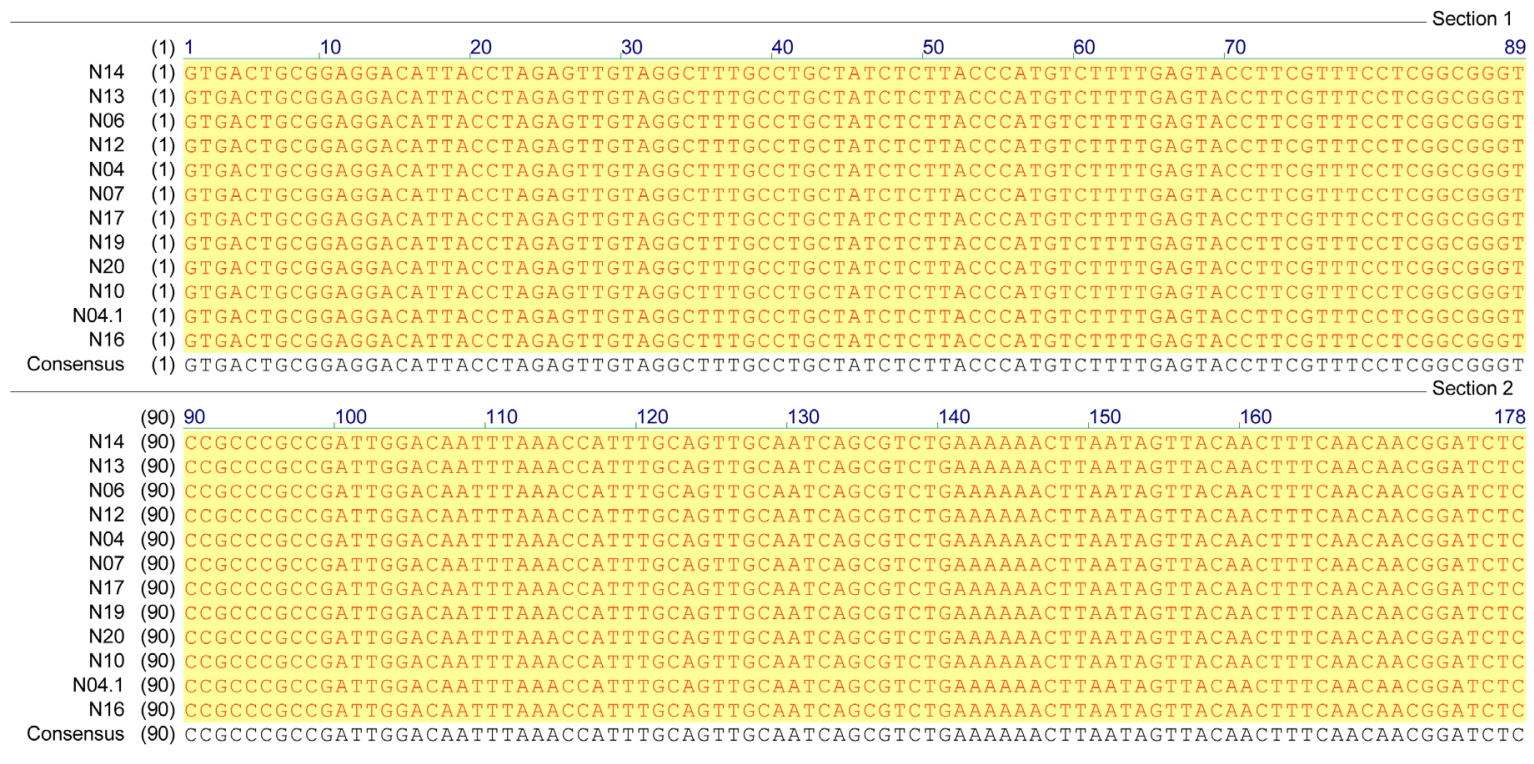

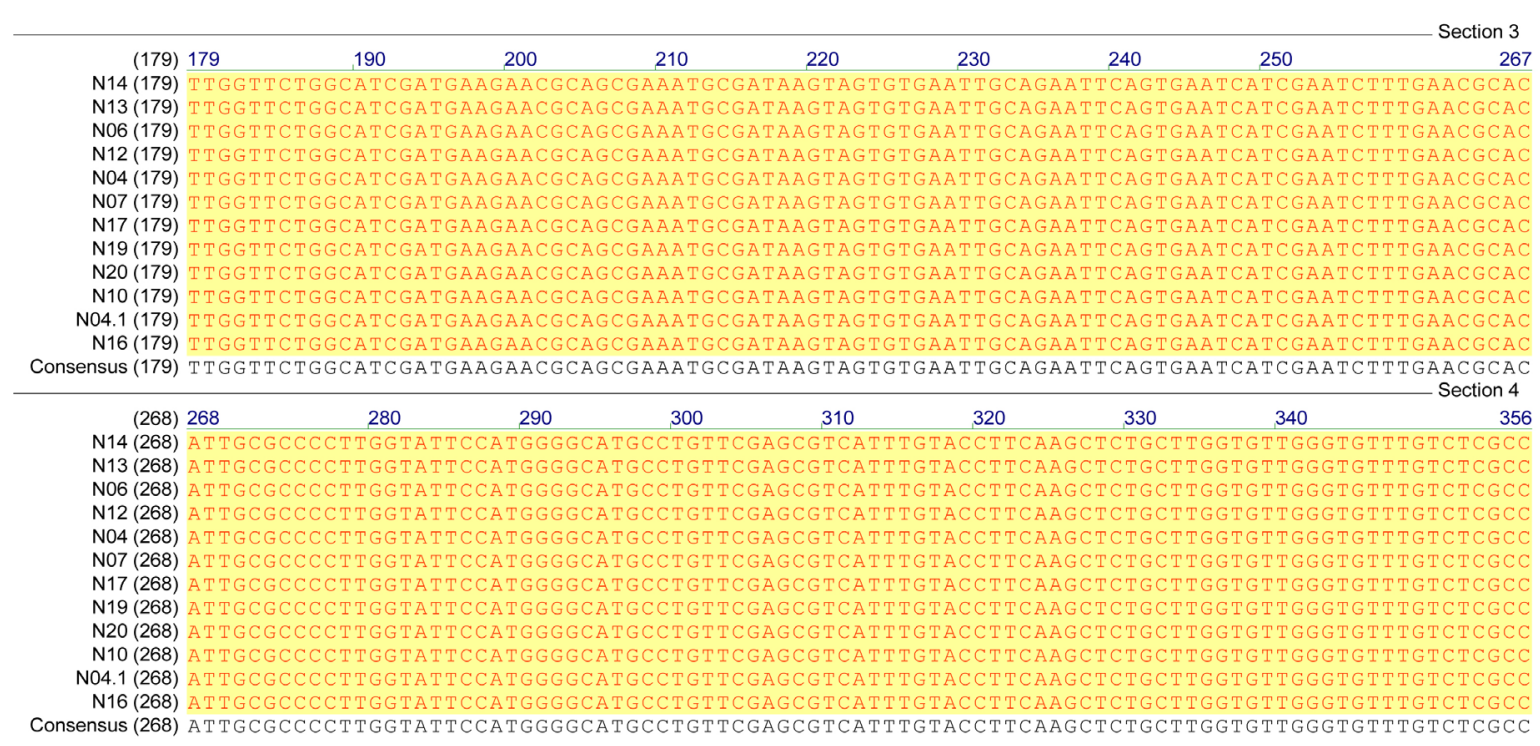

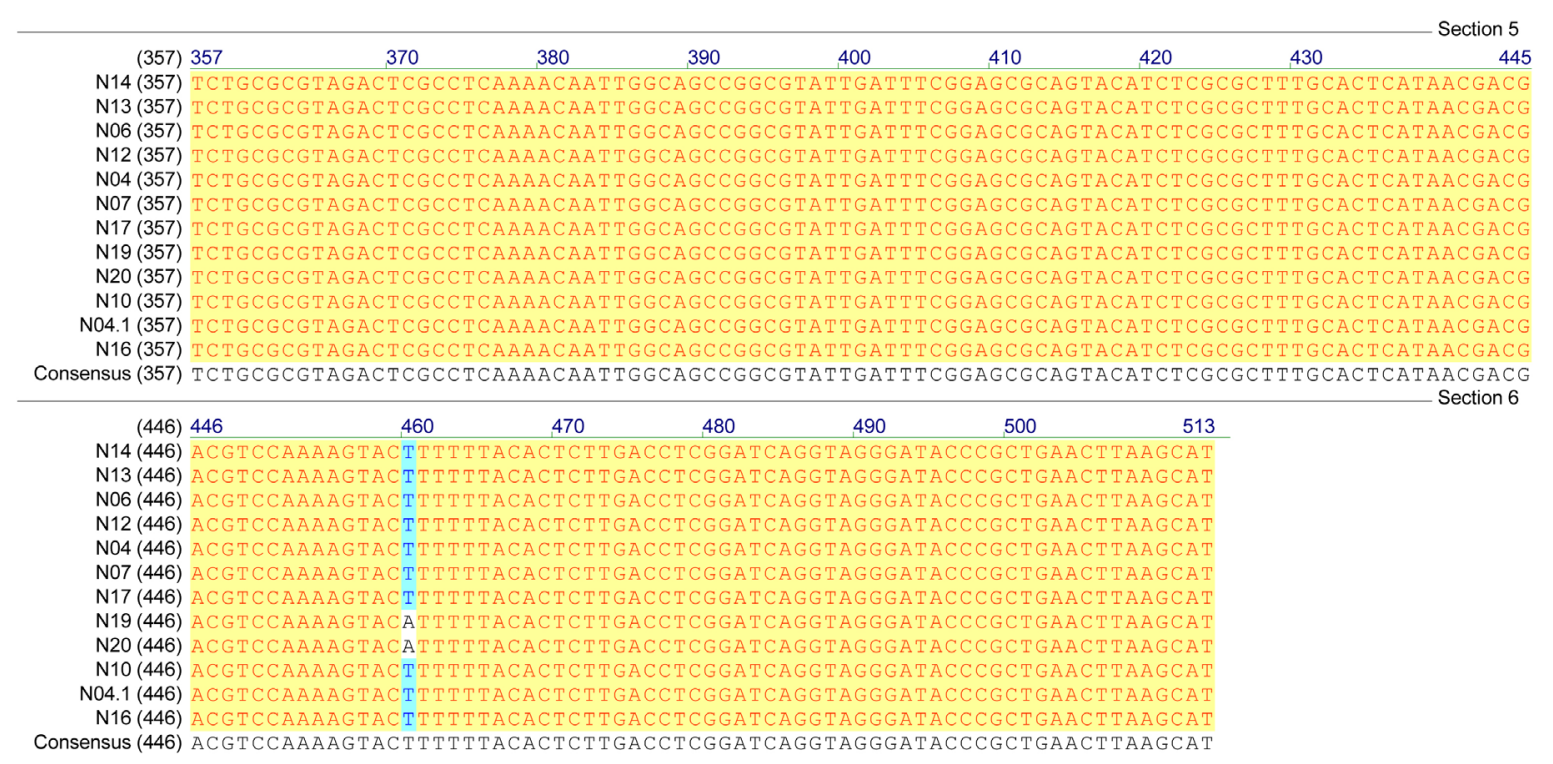

Appendix 1. Alignment of ITS sequences obtained with primers ITS1-F and ITS4-B from the Belarusian samples. 


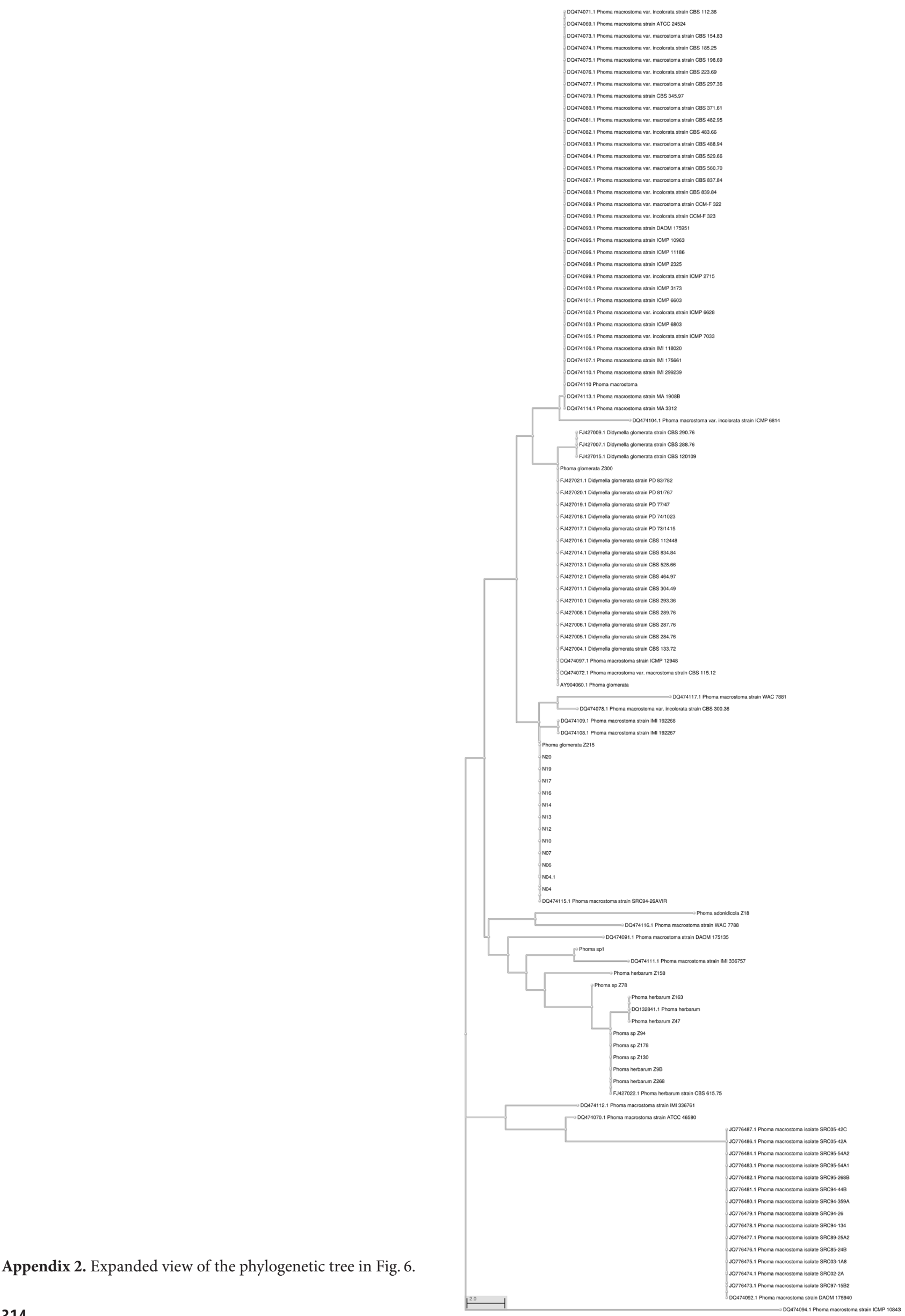

